\title{
Transfer of gene conferring herbicide bialaphos resistance into buckwheat plants
}

\author{
M. A. Rubtsova, B. A. Levenko, L. K. Taranenko, I. N. Stekhin, A. I. Sayaz \\ Institute of Plant Physiology and Genetics of Academy of Sciences of Ukraine \\ 31/17 Vasilkivska str., Kyiv, 252022, Ukraine
}

\begin{abstract}
Bar gene conferring resistance to herbicide bialaphos (phos phinithricin) was cloned from Streptomyces hygroscopicus. Bar gene under 355 promoter of cauliflower mosaic virus was introduced in binary pBin19 vector and constructed plasmid was iransferred into Agrcbacterium tumefaciens strain. Conditions of genetic transformation of cultivaled buckwheat and interipecific hybrid Fagopirum esculentum $\times F$. tataricum were worked out. Buckwheat explants were inoculcted by the strain with a plasmid carrying bar gene nearby NPTII gene. Molecular analysis of 8 regenerc ted plants that were selected for kananycin. resistance was performed. 5 plants gave positive signal by do1-and Southern hybridization using as a probe DNA fragment with bar gene that is an evidence of integration of bar gene into plant genome. Transformed plants grow and rooted at Basta concentrations in the mediun that tolally inhibited nontronsformed plants.
\end{abstract}

Introduction. The implementation of herbicides in modern agriculture is inevitable [1]. They control the weed growth and thus increase harvest [2]. Use of herbicides of a new generation that are very effective and as a rule inhibit single definite enzyme at very low concentration is very altractive. These herbicides are not toxic for human and animals. The ecological safety is connected to their quick degradation in soil and absence of target enzymes in vertebrates $[1,3]$.

Bialaphos is an example of a herbicide of this gencration. It is a tripcptide and its acting substance is phosphinothricin (PPT) a toxic analog of glutamic acid [4]. But bialaphos as many other herbicides of this generation is not selective, inhibiting the growth of any plant and this character diminished the use of these herbicides in agriculture. Using gene engineering approach by introducing into plant genome of gene(s) conferring resistance to herbicides of this type it is possible to produce transgenic plants resistant to these herbicides $[5]$.

The source of these genes is soil and other microorganisms. Bialaphos resistance gene (bar) was found in the genome of bialaphos producing streptomyces, conferring their resistance to produced tripeptide [4].

(C) A. A. RUBTSOVA, B. A. LEVENKO, 1. K. TARANENKO, 1. N. STEKIIN, A T SAYATI, 1997
Production of transgenic tobacco, potato, tomato, aspen plants resistant to herbicide PPT is reported $[1,3,6,7]$. Earlier we described the introduction of modificd aro $A$ ge le conferring resistance to herbicide glyphosate (Rouldup) into potato, sugarbeet and soybean plants $|\&, 9|$. In this paper we report about transfer of bar gene and its expression in buckwheat plants.

Materials ant Methods. Cloning of bar gene was done from Strepiomyces hygroscopicus using as vectors pUC19 [10], pCAMV [11], pBin19 [12] plasmids.

Alcali plasmiti isolation, restriction, DNA ligation and electrophoretis, DNA clution and its cleaning, transformation of bacteria were done by the described methods $[12,13]$. The binary vectors were transferred by tri-partntal matings to the disarmed Agrobacterium tumefaciens strains $3850[12]$ and LBA 4404.

All the enzyries used in this work were obtained from NPK «Biotekh» (Russia).

In all experiments we used mutant form of buckwheat Homostilnaya with high regeneration potential and hybrici of this form with tartari buckwheat $(\mathbf{k}-17)$. This hybrid was obtained via in vitro culture of immature interspecific embryos [14].

Internodes, fetioles and leaves of these hybrids and Homostilnaya were inoculated by 3850 strain of 
A. tumefaciens by two hours co-cultivation in overnight culture of agrobacteria in the presence of acetosyringone. Then explants were transferred onto Murashige-Skoog basal media with the addition of $1 \mathrm{mg} / \mathrm{l} \mathrm{BA}$ and $0.5 \mathrm{mg} / \mathrm{l}$. NA for plant regeneration. To suppress agrobacteria regrowth and for kanamycin selection (NPTII gene is located on plasmids alongside bar genc) antibiotics kanamycin, carbenicillin and claforan were also added to the culture medium. Explants were cultivated first in the dark and after appearence of regenerants under 16:8-hr photoperiod with constant temperature of $26^{\circ} \mathrm{C}$. Regenerants that came through kanamycin selection were rooted and microclonally propagated. For evaluation of their herbicide resistance thesc regencrants were transferred onto MS medium with $3-30 \mu 1 / 1$ concentrations of PP'T (Basta).

Results and Discussion. It was shown that recombinant $p B A-I$ plasmid conferring bialaphos resistance has additional $1.7 \mathrm{~kb}$ pair Pst fragment. To improve bar gene expression GTG translation initiation codon was changed for cukaryotic ATG codon.

$35 \mathrm{~S}$ promoter of cauliflower mosaic virus and $3^{\prime}$ region from nopalin synthase gene were introduced into bar gene expression cassette. Recombinant $p B A-3$ plasmid was constructed for transfer of bar gene into buckwheat plants using agrobacteria transformation system. For this purpose Hindl/I fragment containing $3.5 \mathrm{~S}$ promoter, bar gene and poly A region of nopalin synthase gene was cloned into corresponding site of pBin 19 binary vector.

Resulting $A$. tumefaciens strains $3850 / p B A-3$ and LBA $4404 / p B A-3$ appeared to be resistant to $10 \mathrm{mg} / 1$ of bialaphos in nutrient nuedium.

Plants regenerated on kanamycin containing medium that was changed every $12-14$ days were analyzed by dot- and Southern blot-hybridization. Out of 8 kanamycin resistant regenerants positive autoradiographic response gave 5 plants: 4 plants of hybrid Homostilnaya $\times \mathrm{k}-17$ and one plant of Homostilnaya that is a proof of bar gene integration into plant's genome (Fig. 1, 2).

These 5 plants were microclonally propagated and transferred into MS medium containing $3,10,15$, 20 and $30,1 / 1$ of herbicioe Basta. On medium added with 3 and $10 \mu \mathrm{m} / 1$ of Basta all these plants formed roots and their growth did not differentiate from the growth of plants on MS medium without herbicide.

At 15 and $20 \mu \mathrm{l} / 1$ of Basta only 2 plants rooted and their development was normal. At $30 \mu \mathrm{l} / 1$ Basta concentration only one plant survived. The growth and rool formation of nontransformed plants of $\mathrm{Ho}$ mostilnaya and Homostilnaya $\times \mathrm{k}-17$ hybrid were inhibited aiready at $3 \mu l / l$ of Basta.

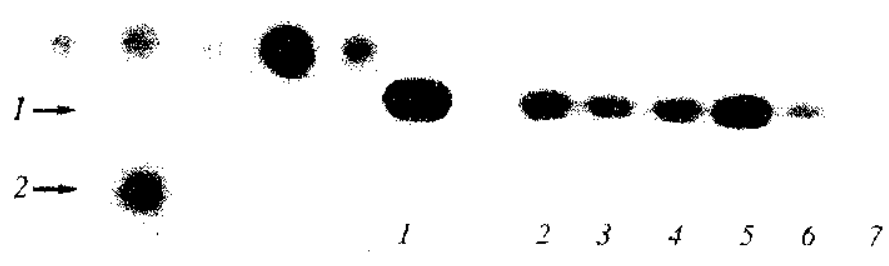

Fig. 1. DNA dot-hyt ridization of buckwheat plants Arrows show negative ( $I$ ) and positive (2) controls. Intensive black spots correspond to DNA of ptants with positive autoradiographic response

Fig. 2. DNA Southern hybridization of buckwheat plants: 1 positive control (Hindlll fragment with bar-gene); 2-6-DNA of buckwheat plants after HindII restriction with positive autoradiographic response; 7 - negative control (ONA of nontransgenic buckwheat plants)

That is a difference among transformed plants by the level of traisferred bar gene expression was clearly seen.

М. О. Рубцива, Б. О. Лсяенко, Л. К. Тараненко, І. М. Стехін, O. I. $3 a \epsilon \mu b$

Перенссенเя гена спійкості до гербіциду біаларосу в рөслини грсчки

Резюме

Iз Streptomyces hygroscopicus клонуяали bаr-zен, який визначас стійкість do гербіц dу бiatuфосу (фосфінотрицину). Ген nid контролем 35 -промомора вірусу мозаїки цвімної капусти було ввеdено у бінерний вектор рвіпlя для трансформациї рослин. Одержану рехомбінантну плазміду перенесено до имаmy 3850 Agrobacterium tumefaciens. Midicpano ysuau mpaнсформацї культурнӧ̈ госчки і міжвидового гібрида Fаgоругит esculentum $\times$ F. taturi:um. Eкспланти гренки інокулювали асробактеріальним иітамом, у якому ьат-ген знаходиться на $T_{i}$

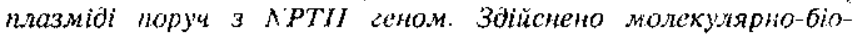
ногічлий аналіз восьми ресенеранпів, які пнойнли канаміциновий відбір. П'янь рослин дали позитивну радіоавтографімну віоповідь при дот- $i$ Саузерн-сібридизаиї з міченим

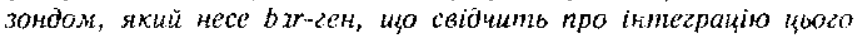
гена о геном рослин. Трансформовані рослини росли і утворювали коріння при концентрації гербіцида басти в середовииі, яке повніспю пригнічувало нетрансфориовані рослини.

М. А. Рубиова, Б. А. Левенко, П. К. Тараненко, И. Н. Стехии, A. $И .3 a$ sin

Перенос гена устойчивости к гербициду биаласосу в растения гречихи

Резюме

Из Streptomyces hygroscopicus клонировали bат-ген, определяющий устойтивость к сербициду биалафьосу (фосфинотрииину) Ген под контролем 35 S-промотора вируса мозаихи цветной капусты был введен в бинарньй вектор рВіп19 для трансфор- 
маини растиний. Нолученая реклибинантная плазмида переuecera 3 umamm 3850 Agrobacterium lumefaciens. IJoбoбparal условия трансдор.ноция культурнй грецихи и межвидового zuбpuda Fagopyrum escuientum $\times F$. tataricum. $3 к с n л а н m b$ грешuхи инокулировали асроб́актериальном ыитаммом, в иотором bar-вен находилs: на $T_{i}$ плазмиде рядом с геном NPTIl. ІІроведен молекулярно-биологшиеский анализ восьми реzенкранmog, проитдаих канамицинозый опбор. /ямь распений дали

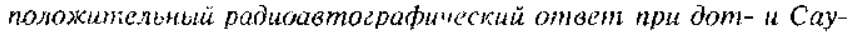
зерн-сибридизации с меченым зонолк, несуици ьат-еск, ито свидетельспиует өб интеграции эмого еена в геном растений. Трансформирозанные растения росли и образовывали корни при концентрации гербицида басты в среде, полпостью инсибирующей н'трансформированные растенияі.

\section{RETEREVCES}

1. Botterman $J$, Lecmans $J$. Engineering herbicide resistance in plants // TIG. -1988 - -4.-T. 219--222.

2. De Greef $W$., Delon $R$., De Block $M$. et al. Evaluation of herbicide resistance in transgenic crops utider field conditions // Biotechnology. $-1989 .--7 .-$ P. $61--65$.

3. De Block $M$., Botterman $J$, Vandewiete $M$. et al. Engineering herbicide resistance in planis by expression of a detoxifying enzyme // EMBO J.-1987.-6.-P. 2513-2518.

4. Murakami $\gamma$., Anzai H., Ihai $S$. et al. The bialaphos genes of Streptomyces hygroscopicus: Molecular cloning and characterization of genc cluster // Mol, and Gen. Genet.-1986.205.-P. $42-50$.

5. Piruzian E. S., Mett V. L., Kobets N. S., Urmeeva F. I. The use of bacterial genes encoding herbicide tolerance in constructing transgenic plants // Microbiol. Sci.-1988.-5.P. $242-247$.

6. Devillard C. Transformation in vitro du Iremble (Populus tremulo $\times$ Populis alba) par Agrobacterium rhizogenes et regeneration de plantes toierantes au basia // C. r. Acad. Sci. Paris. Biotechnol.-1922,-314,-P. 291-298.

7. De Greef $W$., Delon $R$, De Block $M$. et al. Evuluation of herbicide resistance in tranigenic crops under field conditions // Biotechnolod $\%-1988 .-7 .-\mathrm{P} .61-64$.

8. Левенко Б. А., Стехин И. Н., Билека Г. М. и др. Введение гена устойчивости к глифосату в растения картофеля и сахарноӥ свехлы // Физиология и биохимия культур. растений. $-1993 .-25 .-$ C. $197-200$.

9. Levenko B. A., Maryushkin V. F., Steknin $I . N$. et al. Obtaining soybean plants resistant to herbicide glyphosate // All Union 7th. Symp. «Trends in Plant Biotechnol».--Moscow, $1991,-$ P. 131.

10. Yanish O., Perron C., Viera J., Messing J. Improved M13 of the $\mathrm{M} \backslash 3 \mathrm{mpl} 18$ and $p U C / 9$ vectors // Gene.-1985.-33.P. $103-119$.

11. Fromm L. E.,T'ylor L. P., Walbot V. Stable transiormation of maize after get:e transfer by clectroporation // Nature.1986. -319.-P. $791-793$.

12. Draper J., Scot1 $R$., Armitage $P$. Plant genetic transformation and gene expression.-Oxford, 1988.-P'. 8-62.

13. Маниатис E., Фрии 3., Сзмбрук д. Молекупярное клонирование.-М : Мир, 1984.-480 С.

14. Рубиова М. А., Левенко Б. А., Тараненко Jl. К., Шаповал А. И. ГПолучение межвидовых гибридов между грецихой об́ыкновенной и тречихой татарской с помощью эмбрикульгуры // Физиология и биохимия культур. растений.1994.-26, № 6.-C. $563-566$. 